\title{
Inhibition by Isoniazid of Synthesis of Mycolic Acids in Mycobacterium tuberculosis
}

\author{
By F. G. WINDER AND P. B. COLLINS \\ Department of Biochemistry, University of Dublin, Trinity College, \\ Dublin 2, Ireland
}

(Accepted for publication 15 June 1970)

SUMMARY

\begin{abstract}
Exposure of growing Mycobacterium tuberculosis BCG to I $\mu \mathrm{g}$. isoniazid $/ \mathrm{ml}$. inhibited the incorporation of ${ }^{14} \mathrm{C}$ from $\left[\mathrm{U}-{ }^{14} \mathrm{C}\right]$ and $\left[2-{ }^{14} \mathrm{C}\right]$ glycerol and $\left[\mathrm{I}^{14} \mathrm{C}\right]-$ glutamate into its walls by about $50 \%$ over $\mathrm{I} 2 \mathrm{~h}$. because ${ }^{14} \mathrm{C}$ incorporation into the mycolic acids of the walls was prevented. Isoniazid, $0.5 \mu \mathrm{g} . / \mathrm{ml}$. with $M$. tuberculosis BCG or $0.1 \mu \mathrm{g} . / \mathrm{ml}$. with $M$. tuberculosis $\mathrm{H} 37 \mathrm{Ra}$, inhibited incorporation of ${ }^{14} \mathrm{C}$ from $\left[\mathrm{U}-{ }^{14} \mathrm{C}\right]$ glycerol into total mycolic acids by about $90 \%$ over $6 \mathrm{~h}$., indicating that inhibition began within $\mathrm{I}$ h. of the addition of the drug. There was no effect on mycolic acid synthesis in an isoniazidresistant strain of $M$. tuberculosis BCG. The primary inhibitory action of isoniazid in sensitive mycobacteria is probably on mycolic acid synthesis, and this leads to formation of defective boundary layers of the bacteria.
\end{abstract}

\section{INTRODUCTION}

A detailed examination of the effects of isonicotinic acid hydrazide (isoniazid) on the carbohydrates of Mycobacterium tuberculosis suggested that this drug interferes with the formation of the cell envelope of this organism (Winder \& Rooney, 1970). Other lines of evidence, discussed by these authors, support this conclusion. This present paper gives an account of subsequent studies into the inhibition of mycolic acid synthesis by isoniazid. Some of these results have appeared in preliminary form (Winder, Collins \& Rooney, 1970).

\section{METHODS}

Organisms and growth conditions. Mycobacterium tuberculosis, var. bovis, strain BCG was obtained from Glaxo Laboratories Ltd, Greenford, Middlesex. The isoniazidresistant strain was obtained by transfer of a heavy inoculum onto Löwenstein-Jensen medium containing Ioo $\mu \mathrm{g}$. isoniazid $/ \mathrm{ml}$., followed by repeated subculture on the same medium. Mycobacterium tuberculosis, var. hominis, strain H37 Ra was obtained from Trudeau Laboratories, Saranac Lake, New York, U.S.A. Both organisms were grown in shaken culture at $37^{\circ}$ as previously described (Winder, Brennan \& McDonnell, 1967). The medium was based on Sauton medium (Soltys, I952), but had less glycerol $(7 \cdot 55 \mathrm{~g} . / 1$.$) and asparagine was replaced by \mathrm{I} \cdot 2 \mathrm{~g}$. monosodium glutamate/l.

Exposure to $\left[{ }^{14} \mathrm{C}\right]$ glycerol and isoniazid. After about 9 days similar small amounts of $\left[2^{-14} \mathrm{C}\right]$ glycerol or $\left[\mathrm{U}^{14} \mathrm{C}\right] \mathrm{glycerol}$ of high specific activity was added to each culture. Isoniazid was simultaneously added to half of the cultures, the remainder serving as controls, and both sets of cultures were harvested after 6 or $\mathrm{I} 2 \mathrm{~h}$. by filtration through 
Whatman no. I paper in a Büchner funnel. The collected material was washed several times on the filter with $0.9 \%(\mathrm{w} / \mathrm{v}) \mathrm{NaCl}$, the fluid removed by suction and the bacteria weighed (wet weight).

Preparation of bacterial walls. The bacteria were suspended in $67 \mathrm{~mm}$-phosphate buffer, $\mathrm{pH} 7.8$ ( $\mathrm{lO} \mathrm{g}$. wet wt of bacteria to $50 \mathrm{ml}$. of buffer), cooled in ice and treated for $20 \mathrm{~min}$. with a I00 W $20 \mathrm{kHz}$ ultrasonic generator (Soniprobe type I I $30 \mathrm{~A}$, Dawe Instruments Ltd, London W.3), turned to maximal output. The homogenate was then fractionated as described by Kotani, Kitaura, Hirano \& Tanaka (1959) to give a $330 \mathrm{~g}$ sediment (unbroken bacteria and clumps), a $4200 \mathrm{~g}$ sediment (crude-wall fraction) and a $4200 \mathrm{~g}$ supernatant. The crude-wall fraction was treated with trypsin, as described by Kotani et al. (1959), after which the residue was freeze-dried. To remove unbound lipids, the walls were then treated for 2 days with chloroform + methanol $(2+I, v / v)$ at room temperature, centrifuged after adjustment of the chloroform: methanol ratio to unity, and the residue extracted with ethanol + water $(\mathrm{I}+\mathrm{I}, \mathrm{V} / \mathrm{v})$ at $40^{\circ}$ for $\mathrm{I} \mathrm{h}$. The residue of purified cell walls was then dried in vacuo. The chloroform + methanol and ethanol+ether extracts were pooled to provide the unbound lipids.

Extraction of mycolic acids from bacterial walls. Purified walls were saponified by refluxing with $2.5 \%(\mathrm{w} / \mathrm{v}) \mathrm{KOH}$ in methanol+benzene $(\mathrm{I}+\mathrm{I}, \mathrm{v} / \mathrm{v})$ for $6 \mathrm{~h}$. After removing the insoluble residue by centrifuging, the extract was adjusted to $\mathrm{pH} 4^{\circ}$, and mycolic acids (along with other fatty acids and possibly other lipids) were extracted with ether. Mycolic acids were precipitated from the etheral extract by adding two volumes of ethanol, separated by centrifugation and dried in vacuo.

Extraction of mycolic acids and other fatty acids from whole bacteria. The bacteria were extracted three times with ethanol + ether $(3+\mathrm{I}, \mathrm{v} / \mathrm{v})$ at $60^{\circ}$ for $\mathrm{Io} \mathrm{min}$. to remove unbound lipids. The extracts were pooled, evaporated to dryness, saponified and fatty acids extracted as described above. The bacterial residue was then saponified, fatty acids extracted and mycolic acids precipitated as described above.

Thin-layer chromatography of mycolic acids. Mycolic acids were converted to their methyl esters by the use of diazomethane (Lipsky \& Landowne, 1963). The esters were chromatographed on thin-layer plates of silica gel G (E. Merck, A.-G., Darmstadt, West Germany) using light petroleum (b.p. 40 to $\left.60^{\circ}\right)+$ diethyl ether $(9+\mathrm{I}, \mathrm{v} / \mathrm{v})$ as solvent. Samples of authentic mycolic acid esters (gifts from Dr P. J. Brennan of this Department) were used as standards. Mycolic acid esters and other lipids on the plates were detected by exposing plates to $I_{2}$ vapour or by spraying with Rhodamine $6 \mathrm{G}$. The chromatogram of each sample was divided into $2 \mathrm{~cm}$. bands, the gel removed from each band and its radioactivity counted.

Measurement of ${ }^{14} \mathrm{C}$. All samples were counted in Bray's solution (Bray, I960) containing $2 \%$ Cab-O-Sil (Packard Instrument Company) in a Packard 3380 liquid scintillation counter. The results were converted to d.p.m. using the external standard channels ratio method in conjunction with a quench curve prepared with the same scintillation mixture.

Materials. Isotopically labelled compounds were obtained from The Radiochemical Centre, Amersham, Buckinghamshire. 


\section{RESULTS}

\section{Effects of isoniazid on bacterial wall synthesis}

The incorporation of ${ }^{14} \mathrm{C}$ from $\left[2-{ }^{14} \mathrm{C}\right] \mathrm{glycerol}$ into Mycobacterium tuberculosis BCG and fractions derived therefrom is shown in Table 1 . Over $90 \%$ of the ${ }^{14} \mathrm{C}$ taken up was found in the $4200 \mathrm{~g}$ supernatant and in the $330 \mathrm{~g}$ sediment. Exposure to isoniazid I $\mu \mathrm{g} . / \mathrm{ml}$. for the $\mathrm{I} 2 \mathrm{~h}$. uptake period had no appreciable effect on the total uptake of ${ }^{14} \mathrm{C}$. It had a very slight effect on the relative amounts of radioactivity in the $330 \mathrm{~g}$ sediment and the $4200 \mathrm{~g}$ supernatant fluid; this was probably due to a greater fragility of isoniazid-treated bacteria, which was more apparent when shorter periods of disintegration were used (Winder et al. 1970). Isoniazid slightly decreased the radioactivity in the crude-wall fraction; when this material was further fractionated, the ${ }^{14} \mathrm{C}$ content of the purified walls was half that of the control while there was little effect on the trypsin extract or the free lipid.

\section{Table I. Effect of isoniazid on the incorporation of ${ }^{14} \mathrm{C}$ from $\left[{ }^{14} \mathrm{C}\right] \mathrm{glycerol}$ into Myobacterium tuberculosis $B C G$ and its subcellular fractions}

Fifteen $100 \mathrm{ml}$. cultures were treated with I $\mu \mathrm{g}$. isoniazid/ml. for $\mathrm{I} 2 \mathrm{~h}$. and the same number used as contro]s. $\left[2-{ }^{14} \mathrm{C}\right] \mathrm{Glycerol}(0.26 \mu \mathrm{Ci} /$ culture $)$ was added to give a final specific activity of approximately 66 d.p.m. $/ \mu$ mole. Yields of bacteria (g. wet wt) were: control, $2 \cdot 6$; isoniazidtreated, $2 \cdot 3$.

$\quad$ Fraction
$330 \mathrm{~g}$ sediment
$4200 \mathrm{~g}$ supernatant
Wall fractions $(4200 \mathrm{~g}$ sediment $)$
Trypsin extract
Unbound lipid
Purified walls
Total in bacteria
Purified walls
Purified walls

\begin{tabular}{|c|c|}
\hline \multicolumn{2}{|c|}{${ }^{14} \mathrm{C}$ content (d.p.m.) } \\
\hline Control & Isoniazid-treated \\
\hline 127,000 & I I I , , O0 \\
\hline I 89,000 & 207,000 \\
\hline 20,000 & 17,000 \\
\hline 4,000 & 3,800 \\
\hline 5,900 & 3,000 \\
\hline 346,000 & 342,000 \\
\hline \multicolumn{2}{|c|}{ Yield (mg. dry wt) } \\
\hline $12 \cdot 6$ & $14{ }^{\circ} \mathrm{O}$ \\
\hline Specific acti & p.m./mg. dry wt) \\
\hline 468 & 214 \\
\hline
\end{tabular}

Further experiments confirmed this result. In three separate experiments, the incorporation of ${ }^{14} \mathrm{C}$ from $\left[2-{ }^{14} \mathrm{C}\right]$ glycerol into purified walls over $12 \mathrm{~h}$. in the presence of I $\mu \mathrm{g}$. isoniazid $/ \mathrm{ml}$. was $0.5 \mathrm{I} \pm 0.03$ (S.E.M.) of the control incorporation, and in two further experiments the incorporation in the presence of $\mathrm{I} 0 \mu \mathrm{g}$. isoniazid $/ \mathrm{ml}$. was $0.38 \pm 0.08$ of the control. In neither set of experiments did the total incorporation of ${ }^{14} \mathrm{C}$ into the bacteria in the presence of isoniazid differ appreciably from the control value. Thus isoniazid had a specific inhibitory effect on the incorporation of carbon from glycerol into the cell walls of Mycobacterium tuberculosis BCG.

In a similar experiment in which $\left[{ }^{1-14} \mathrm{C}\right]$-DL-glutamate, the other carbon source in the medium, was used at $\mathrm{I} \cdot 25 \mu \mathrm{Ci} / \mathrm{l}$. of medium, the carbon from glutamate was incorporated into walls to a smaller extent than carbon from glycerol. This incorporation was reduced by $20 \%$ during a $\mathrm{I} 2 \mathrm{~h}$. exposure to I $\mu \mathrm{g}$. isoniazid $/ \mathrm{ml}$. Thus isoniazid inhibited the total incorporation of carbon into the bacterial wall.

To identify the wall component whose synthesis was affected by isoniazid, purified 
walls from bacteria which had been exposed to $\left[{ }^{14} \mathrm{C}\right]$ glycerol in the presence and $\mathrm{ab}$ sence of isoniazid were separately saponified and extracted with ether at $\mathrm{pH} 4.0$. Three fractions were obtained: a mycolic acid fraction; an aqueous fraction which contained part of the cell-wall polysaccharide; and a residue mainly of peptidoglycan. Isoniazid strongly inhibited the incorporation of radioactivity into the mycolic acid fraction, had a much smaller effect on incorporation into the aqueous fraction and no appreciable effect on the residue (Table 2). These results suggested that isoniazid had a primary effect on the synthesis of mycolic acid or its incorporation into the wall and that the effect on the polysaccharide fraction was secondary to this.

Table 2. Effect of isoniazid on the incorporation of ${ }^{14} \mathrm{C}$ from $\left[{ }^{14} \mathrm{C}\right]$ glycerol into fractions obtained on saponification of purified walls of Mycobacterium tuberculosis $B C G$

Seventeen $100 \mathrm{ml}$. cultures were treated with I $\mu \mathrm{g}$. isoniazid $/ \mathrm{ml}$. for $\mathrm{I} 2 \mathrm{~h}$. and the same number used as controls. $\left[2-{ }^{14} \mathrm{C}\right] \mathrm{Glycerol}(0.63 \mu \mathrm{Ci} /$ culture $)$ was added to give a final specific activity of approximately 168 d.p.m./ / mole. Yields of bacteria (g. wet wt) were: control, $15 \cdot 5$; isoniazid-treated, $15 \cdot 4$.

Fraction
Purified walls
Mycolic acids
Aqueous fraction
(polysaccharide)
Insoluble residue

\begin{tabular}{|c|c|}
\hline \multicolumn{2}{|c|}{${ }^{14} \mathrm{C}$ content (d.p.m.) } \\
\hline Control & Isoniazid-treated \\
\hline 2,944 & $\mathrm{I}, 508$ \\
\hline 768 & I 26 \\
\hline $\mathrm{I}, \mathrm{I} I \mathrm{I} 2$ & 552 \\
\hline 800 & 694 \\
\hline
\end{tabular}

Table 3. Effect of isoniazid on the incorporation of ${ }^{14} \mathrm{C}$ from $\left[{ }^{14} \mathrm{C}\right] \mathrm{glycerol}$ into fatty acids from free and bound lipids of Mycobacterium tuberculosis $B C G$

Six $100 \mathrm{ml}$. cultures were used for each treatment $(6 \mathrm{~h}$.). [U-14 $\mathrm{C}] \mathrm{Glycerol}(\mathrm{I} \cdot 25 \mu \mathrm{Ci} / \mathrm{culture})$ was added to give a final specific activity of approximately 333 d.p.m. Yields of bacteria (g. wet wt) were: control, $\mathrm{I} \cdot 0$; with $0 . \mathrm{I} \mu \mathrm{g}$. isoniazid $/ \mathrm{ml}$., $\mathrm{I} \cdot 2$; with $\mathrm{I} \mu \mathrm{g}$. isoniazid $/ \mathrm{ml} ., 0 \cdot 9$.

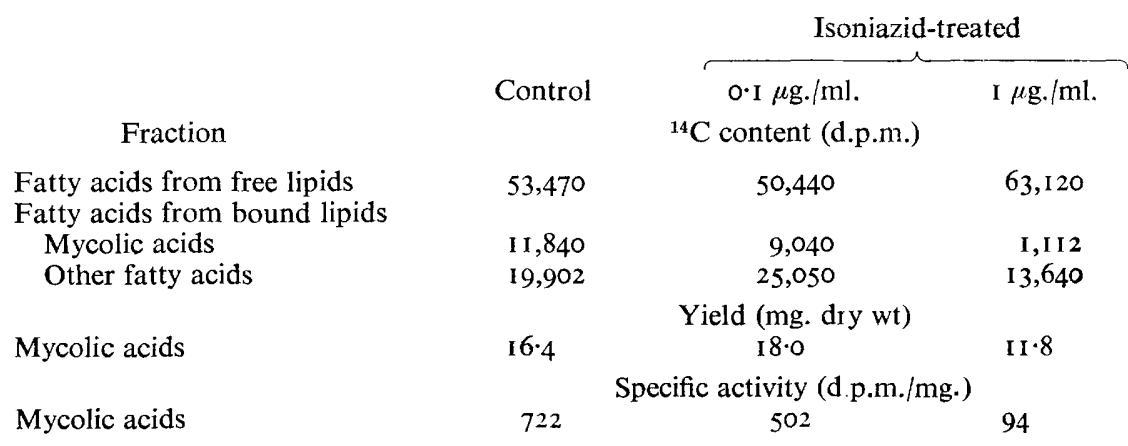

\section{Effects of isoniazid on mycolic acid synthesis}

To determine whether this effect of isoniazid was on the synthesis of mycolic acid or on its incorporation into the wall, experiments were made in which the total mycolic acid was extracted from Mycobacterium tuberculosis BCG which had been exposed to $\left[{ }^{14} \mathrm{C}\right]$ glycerol for $6 \mathrm{~h}$. with and without isoniazid. The results of a typical experiment (Table 3) showed that isoniazid $0 . \mathrm{I} \mu \mathrm{g} . / \mathrm{ml}$. slightly inhibited the synthesis of mycolic acid and that it had a strong inhibitory effect at $\mathrm{I} \mu \mathrm{g} . / \mathrm{ml}$. Other experiments showed 
that results with $0.5 \mu \mathrm{g} . / \mathrm{ml}$. were similar to those with I $\mu \mathrm{g} . / \mathrm{ml}$. Effects on the free lipids, and on the non-mycolic fatty acids and related compounds of the bound lipid fraction were relatively small.

Since incorporation of ${ }^{14} \mathrm{C}$ from $\left[{ }^{14} \mathrm{C}\right]$ glycerol in the medium into the mycolic acid of control bacteria is effectively linear under these experimental conditions for the period involved (F. G. Winder, P. J. Brennan \& S. A. Rooney, unpublished observations), the degree of inhibition by $\mathrm{I} \mu \mathrm{g}$. isoniazid/ml. of incorporation of ${ }^{14} \mathrm{C}$ into mycolic acid over a $6 \mathrm{~h}$. period indicated that it produced an inhibition of synthesis of mycolic acid between $90 \%$ immediately and $100 \%$ after a delay of less than $\mathrm{I} \mathrm{h}$. In view of this degree of inhibition, we conclude that the synthesis of all the mycolic acids present in major amount in this organism was affected.

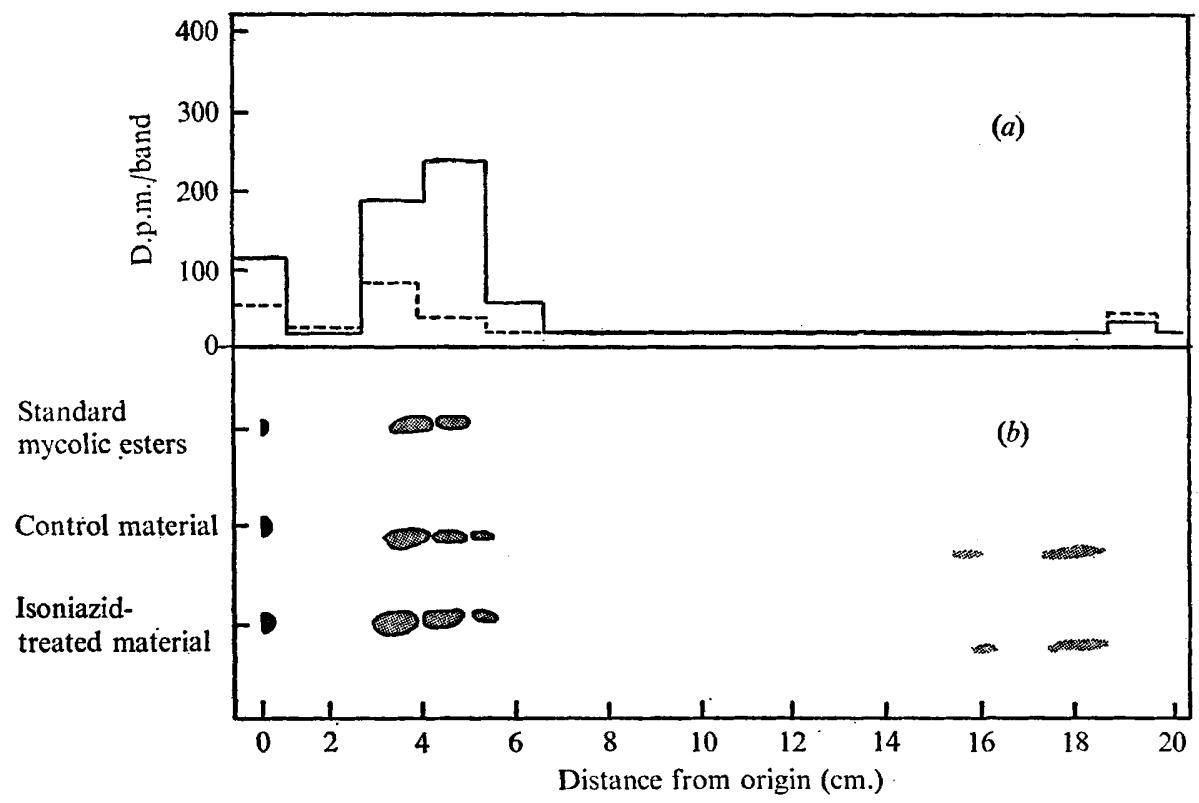

Fig. I. Thin-layer chromatography of the methylated mycolic acids from the bound lipids of Mycobacterium tuberculosis $\mathrm{BCG}$ which had been exposed to [2-14 C]glycerol with and without $\mathrm{I} \mu \mathrm{g}$. isoniazid $/ \mathrm{ml}$. for $6 \mathrm{~h}$. (a) Distribution of radioactivity in chromatograms of control (-) and isoniazid-treated (--) material. (b) Diagram of spots on plate after exposure to iodine vapour.

Thin-layer chromatography of the methyl mycolates showed that they were contaminated with small amounts of fatty acids, but that most of the radioactivity in the case of mycolic acids from the control cells was associated with the mycolic acid area of the plate (Fig. I). The amount of radioactivity associated with the mycolic acid area from isoniazid-treated cells was much less than with that from control cells. Separation of different components of the mycolic acid fraction was only slight with the chromatographic system used, but the chromatograms confirmed that the major mycolic acid components were all affected by isoniazid, though there was some suggestion that not all were affected equally.

In contrast to the above results with an isoniazid-sensitive strain of $\mathrm{BCG}$, isoniazid 
did not inhibit the incorporation of ${ }^{14} \mathrm{C}$ into the mycolic acids of an isoniazid-resistant strain (Table 4).

When similar experiments were made with isoniazid-sensitive Mycobacterium tuberculosis $\mathrm{H} 37 \mathrm{Ra}$, it was found that isoniazid at $0.1 \mu \mathrm{g} . / \mathrm{ml}$. led to almost complete inhibition of mycolic acid synthesis over $6 \mathrm{~h}$. (Table 5).

\section{Table 4. Effect of isoniazid on the incorporation of ${ }^{14} \mathrm{C}$ from $\left[{ }^{14} \mathrm{C}\right]$ glycerol into} mycolic acids of isoniazid-resistant Mycobacterium tuberculosis BCG

Nine $100 \mathrm{ml}$. cultures were treated with $\mathrm{I} \mu \mathrm{g}$. isoniazid $/ \mathrm{ml}$. for $6 \mathrm{~h}$. and the same number used as controls. [U- $\left.{ }^{14} \mathrm{C}\right] \mathrm{Glycerol}(\mathrm{I} \cdot 25 \mu \mathrm{Ci} /$ culture $)$ was added to give a final specific activity of approximately 333 d.p.m./ $\mu$ mole. Yields of bacteria (g. wet $\mathrm{wt}$ ) were: control, $\mathrm{I} \cdot 2$; isoniazidtreated, $1 \cdot 4$.

$\begin{array}{lrcc} & \text { Control } & \text { Isoniazid-treated } \\ \text { Total }{ }^{14} \text { C mycolic acids } & \text { I4, I08 } & \text { d.p.m. } & \text { I7,736 } \\ \text { Yield of mycolic acids } & 29 \cdot 8 & \text { mg. dry wt } & 34 \cdot 2 \\ \text { Specific activity of mycolic acids } & 474 & \text { d.p.m. } / \mathrm{mg} . & 519\end{array}$

Table 5. Effect of isoniazid on the incorporation of ${ }^{14} \mathrm{C}$ from $\left[{ }^{14} \mathrm{C}\right]$ glycerol into mycolic acids of Mycobacterium tuberculosis $\mathrm{H} 37 \mathrm{Ra}$

Five $100 \mathrm{ml}$. cultures were treated with $0 . \mathrm{I} \mu \mathrm{g}$. isoniazid $/ \mathrm{ml}$. for $6 \mathrm{~h}$. and the same number used as controls. [U-14 $\mathrm{C}] \mathrm{Glycerol}(2 \cdot 5 \mu \mathrm{Ci} /$ culture $)$ was added to give a final specific activity of approximately $666 \mathrm{~d} . \mathrm{p} . \mathrm{m} . / \mu$ mole. Yields of bacteria (g. wet wt) were: control, 0.68 ; isoniazid-treated 0.58 .

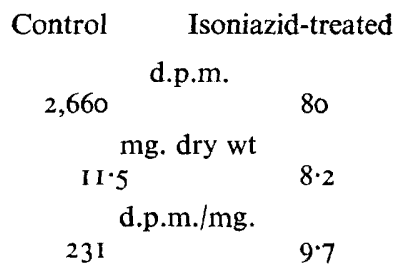

\section{DISCUSSION}

These results show that isoniazid at $0.5 \mu \mathrm{g} . / \mathrm{ml}$. and upwards produced complete, or almost complete, inhibition of synthesis of mycolic acids in $\mathbf{I} \mathrm{h}$. or less in growing Mycobacterium tuberculosis BGC, while total incorporation of carbon into the cells as a whole was substantially unaffected for much longer periods. Isoniazid at $0.1 \mu \mathrm{g} . / \mathrm{ml}$. gave even more rapid and complete inhibition of synthesis of mycolic acids in $M$. tuberculosis $\mathrm{H} 37 \mathrm{Ra}$.

Two questions arise. First, is this inhibition related to the bactericidal action of the drug or is it some completely unrelated phenomenon? The fact that this inhibition occurred to a marked extent in both sensitive strains at isoniazid concentrations close to the minimal inhibitory ones under the conditions of the experiment, but did not occur under similar conditions with an isoniazid-resistant strain, is strong evidence that this effect is related to the bactericidal action of the drug. This conclusion is supported further in that isoniazid also inhibits mycolic acid synthesis in Myco- 
bacterium smegmatis and $M$. phlei but requires higher concentrations, proportional to their minimal growth inhibitory ones (P. J. Brennan, P. B. Collins \& F. G. Winder, unpublished observations).

The second question which arises is, accepting that inhibition of mycolic acid synthesis is related to the bactericidal action of isoniazid, where does it fit into the chain of events involved? We suggest that inhibition of mycolic acid synthesis leads to the formation of envelope material low in mycolic acid and hence defective, that this results in loss of further materials from the boundary layers of the bacteria, and that it leads ultimately to loss of acid-fastness and death. We base this hypothesis partly on evidence in the present paper but mainly on evidence discussed elsewhere (Winder \& Rooney, 1970). The inhibition of mycolic acid synthesis is established quickly as compared with the time required for most other observed effects of isoniazid (see Win der 1964; Youatt, I969), while most such effects can be interpreted in terms of it (Winder \& Collins, 1969; Winder \& Rooney, 1970). The only effects of isoniazid action, other than inhibition of mycolic acid synthesis, which have been shown to occur within $\mathrm{I} h$. of exposure are the uptake of the drug, its metabolism and the formation of pigments (Youatt, I969); these effects may be involved in its action on mycolic acid synthesis. Hence we suggest that the primary site of the inhibitory action of isoniazid lies somewhere in the biosynthetic pathway to the mycolic acids. Since the biosynthetic pathway to mycolic acids is almost unknown (Étémadi, 1967), we do not suggest which enzyme or enzymes may be sensitive to isoniazid nor a mechanism by which isoniazid acts.

The relatively slight inhibitory effect on the incorporation of radioactivity into the polysaccharide fraction derived from the bacterial walls (Table 2) is presumably an indirect effect of inhibition of mycolic acid synthesis. Some of the polysaccharides in this fraction occur, prior to saponification, as mycolic acid esters (Imaeda, Kanetsuna \& Galindo, 1968) and failure of mycolic acid synthesis may result either in an indirect inhibition of synthesis of the polysaccharides or in their elution from the bacterial envelope, a process for which there is evidence (Winder \& Rooney, 1970).

We thank Dr P. J. Brennan for samples of mycolic acids, and Miss Mairead Kelly and Miss Anne Slevin for technical assistance. This work was supported by grants from the National Science Council, Republic of Ireland, and from the U.S. Public Health Service (AI-07254). P.B.C. was supported by grants from the Department of Education and, subsequently, from The Agricultural Institute, Republic of Ireland.

\section{REFERENCES}

BRAY, G. A. (1960). A simple efficient liquid scintillator for counting aqueous solutions in a liquid scintillation counter. Analytical Biochemistry 1, 279-285.

ÉTÉmADI A.-H. (1967). Corrélations structurales et biogenétiques des acides mycoliques en rapport avec la phylogenèse de quelques genres d'Actinomycétales. Thesis, University of Paris. Paris: Masson and Cie.

IMAEDA, I., KANETSUNA, F. \& GALINDO, B. (1968). Ultrastructure of cell walls of genus Mycobacterium. Journal of Ultrastructure Research 25, 46-63.

Kotani, S., Kitaura, T., Hirano, T. \& Tanaka, A. (1959). Isolation and chemical composition of the cell walls of BCG. Biken's Journal 2, 129-14I.

LIPSKY, S. R. \& LANDOwne, R. A. (1963). The identification of fatty acids by gas chromatography. In Methods in Enzymology, vol. 6, pp. 513-537. Edited by S. P. Colowick \& N. O. Kaplan. New York: Academic Press. 
SolTys, M. A. (1952). Tubercle Bacillus and Laboratory Methods in Tuberculosis, p. 129. Edinburgh: E. and S. Livingstone.

WINDER, F. G. (1964). The antibacterial action of streptomycin, isoniazid and PAS. In Chemotherapy of Tuberculosis, pp. I I I-I49. Edited by V. C. Barry. London: Butterworths.

WINDER, F. G., BRENNAN, P. J. \& MCDonNELL, I. (1967). Effects of isoniazid on the composition of mycobacteria, with particular reference to soluble carbohydrates and related substances. Biochemical Journal 104, 385-393.

WINDER, F. G. \& ColLINS, P. (1969). The effect of isoniazid on nicotinamide nucleotide concentrations in tubercle bacilli. American Review of Respiratory Diseases 100, I0I-I03.

WINDER, F. G., Collins, P. \& Rooney, S. A. (1970). Effects of isoniazid on mycolic acid synthesis in Mycobacterium tuberculosis and on its cell envelope. Biochemical Journal II7, 27 P.

WINDER, F. G. \& ROONEY, S. A. (1970). The effects of isoniazid on the carbohydrates of Mycobacterium tuberculosis BCG. Biochemical Journal II7, 355-368.

Youatr, J. (1969). A review of the action of isoniazid. American Review of Respiratory Diseases 99, 729-749. 